\title{
Resistance inducers and organic fertilizer in Citrus sinensis [L.] Osbeck infected with Candidatus Liberibacter asiaticus bacteria
}

\author{
Zapata-Contreras, Yazmin G. ${ }^{1}$; Osorio-Hernández, Eduardo ${ }^{{ }^{*}}$; Silva-Espinosa, José H. ${ }^{1}$; \\ Saénz-Pérez, Griseida A. ${ }^{1}$; Segura-Martínez, Ma. T. ${ }^{1}$ \\ 1 División de Estudios de Postgrado e Investigación-Facultad de Ingeniería y Ciencias-Universidad Autónoma \\ de Tamaulipas. Centro Universitario Adolfo López Mateos, Gd. Victoria, Tamaulipas, México. G.P. 87000 \\ Tel. 834 3181721, ext. 2111. \\ * Corresponding author: eosorio@docentes.uat.edu.mx
}

Gitation: Zapata-Contreras, Yazmin G., Osorio-Hernández, Eduardo, Silva-Espinosa, José H., Saénz-Pérez, Criseida A., Segura-Martínez, Ma. T., (2021). Resistance inducers and organic fertilizer in Citrus sinensis [L.] Osbeck infected with Candidatus Liberibacter asiaticus bacteria. Agro Productividad. https://doi.org/10.32854/agrop. v14i8.1945

Editor in Chief: Dr. Jorge Cadena Iñiguez

Received: March, 2021

Accepted: July, 2021.

Estimated publication date: September, 2021

This work is licensed under a Creative Commons Attribution-NonCommercial 4.0 International license.
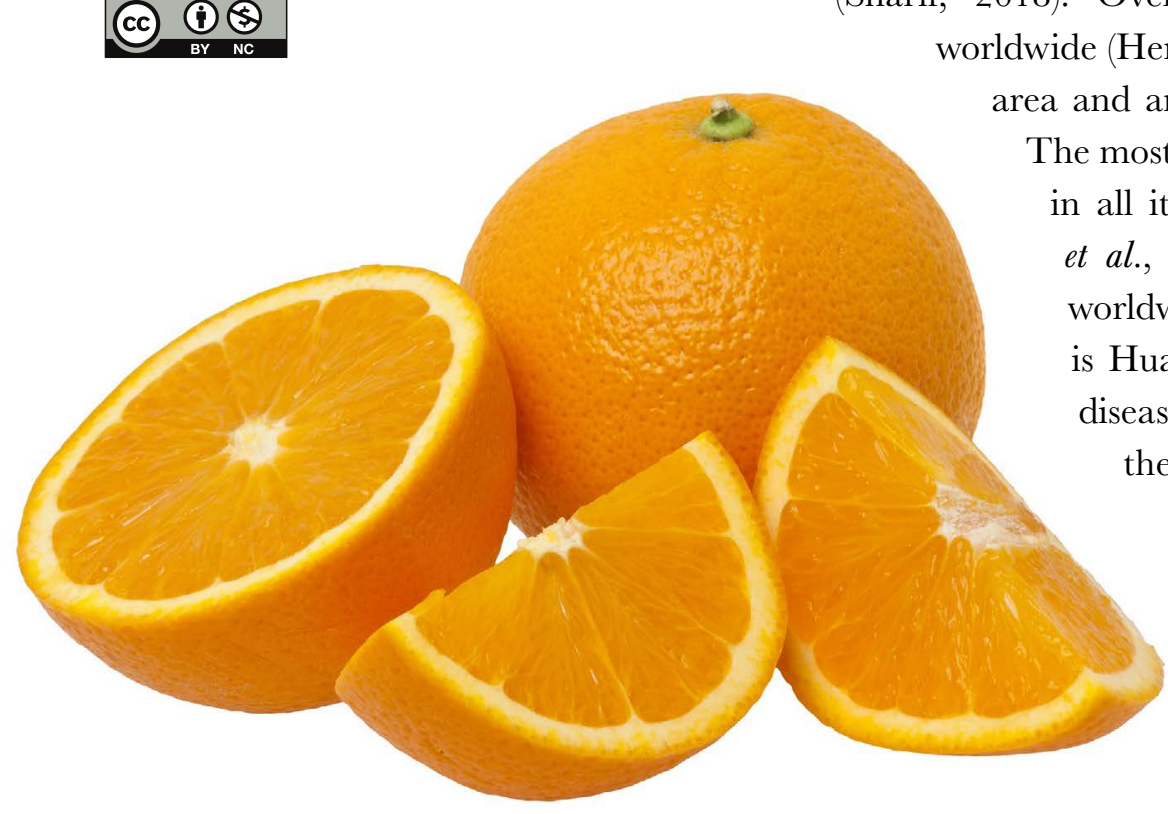
greater fruit weight and diameter.

\section{INTRODUCTION}

\section{ABSTRACT}

Objective: To evaluate the effect of three resistance inducers and an organic fertilizer on the titles of Candidatus Liberibacter asiaticus in Citrus sinensis (L.) Obseck cv. Valencia.

Design/methodology/approach: The treatments consisted of Vacciplant Max and UPL-08, Fosetil aluminum. Likewise, BIO-FOM was applied on the periphery of the trees, with moisture for nutrients absorption. The evaluated variables were fruit weight, equatorial diameter, skin thickness, ${ }^{\circ} \mathrm{BRIX}$, severity and chlorophyll, in each of the five treatments, which consisted of 20 repetitions.

Results: The fruits of the trees treated with Vacciplant Max had lower skin thickness and a higher ${ }^{\circ}$ BRIX. Also, the highest chlorophyll index was recorded with BIO-FOM fertilizer. However, none of the evaluated treatments significantly decreased the fruit harshness.

Findings/conclusions: The best treatment against Huanglongbing was fosetyl aluminum which conferred

Keywords: Nutrients; Huanglongbing; Inductors; Citrus; Dhiaphorina Citri.

Citrus fruits are grown in tropical and subtropical regions of the world (Spreen, 2020) due to their high vitamin $\mathrm{C}$ content. At the same time, it provides multiple benefits to human health and is also used as a raw material in various agro-industrial processes (Sharif, 2018). Overall, México's citrus production is in fourth worldwide (Hernández et al., 2019) with a 590,000 ha cultivated area and an 8 million tons production (Sáenz et al., 2019). important citrus species are sweet orange, lemon al., 2019). In this regard, it should be noted that, worldwide, the most devastating disease for citrus fruits is Huanglongbing (Garza-Saldaña et al., 2017). These disease symptoms are associated with the presence of the Gram-negative $\alpha$-proteobacterium Candidatus Liberibacter asiaticus, spread by the insect vector 
Diaphorina citri (Robles-Gonzales et al., 2017). In Mexico, the disease was detected for the first time in Mexican lemon trees at the Yucatán peninsula in July 2009 (Garza-Saldaña $e t$ al., 2017). Also, along with within the characteristic symptomatology of Huanglongbing, develops an irregular asymmetry and smaller size in fruits, pericarp thickening, seeds abortion, color inversion and reduction of soluble solids, this last characteristic deteriorates the organoleptic quality, which, therefore, is not possible to use it in the juice industry (Sáenz et al., 2019). Currently, there is no known cure for this disease (Curtolo et al., 2020). However, there are various capable resistance inducing chemical agents in plants (Acuña and Grabowski, 2012). In addition to strategies with resistance inducers, antibiotics application and nutrition programs have been developed to delay the disease progress to maintain citrus fruits' yield (Trinidad-Cruz et al., 2019). Resistance inducers require fewer applications, compared to other treatments, likewise, they are an effective means to prevent different pathogens (Ramírez et al., 2012). However, organic fertilizers might be more effective in inducing plant growth, nevertheless, nutrient absorption is lower in foliar applications compared to its direct soil application (Alayón et al., 2014; Ullah et al., 2019).

Due to the above, the following objectives were raised, to determine the severity of the disease in Valencia orange trees treated with resistance inducers and organic fertilizer and estimate the ${ }^{\circ} \mathrm{BRIX}$ of Valencia oranges juice with Huanglongbing, treated with resistance inducers and organic fertilizers.

\section{MATERIALS AND METHODS}

The experiment took place from May 2019 to March 2020 in Citrus sinensis (L.) Obseck cv. Valencia trees, 9 years old, on the citrange rootstock (Carrizo) with typical Huanglongbing symptoms (Previously detected via PCR by the State Committee of Plant Health of Tamaulipas), at the "San Antonio" orchard, located on the Victoria-Santa

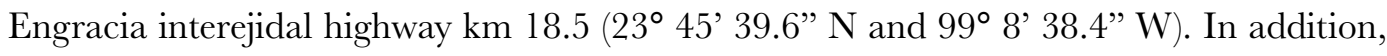
the fruit evaluation was carried out in the Plant Pathology Laboratory of the Central Integral de Laboratories of the Faculty of Engineering and Sciences of the Autonomous University of Tamaulipas, Mexico.

For the treatments of Vacciplant Max and UPL-08 (Table 1), a $132 \mathrm{~mL}$ dose of the agrochemical was applied. For the fosetil aluminum treatment, the dose was $300 \mathrm{~g}$, following the recommended dose of the product. The three treatments were diluted in 100 $\mathrm{L}$ of water and their applications were made with a high-pressure gun connected to a $400 \mathrm{~L}$ sprinkler, between 5:00 p.m. and 7:00 p.m. to avoid elements loss during application due to solar radiation. Also, $4 \mathrm{~kg}$ of $\mathrm{BIO}-\mathrm{FOM}$ per tree were directly applied to a limited area of

Table 1. Treatments (doses and routes of application).

\begin{tabular}{l|c|c}
\multicolumn{1}{c|}{ Treatments } & Dose & Application \\
\hline Vacciplant Max & $132 \mathrm{~mL}$ & Foliar \\
\hline UPL-08 & $132 \mathrm{~mL}$ & Foliar \\
\hline Fosetyl aluminum & $300 \mathrm{~g}$ & Foliar \\
\hline BIO-FOM & $4 \mathrm{~kg}$ & Edafica \\
\hline Control & no application & no application \\
\hline
\end{tabular}


the soil that had humidity, to facilitate nutrients absorption. In all treatments, applications were made every 15 days for two months.

The evaluated variables were fruit weight, equatorial diameter, peel thickness, ${ }^{\circ} \mathrm{BRIX}$, severity and chlorophyll content. In addition, the fruit weight $(\mathrm{P})$ was determined with an analytical balance, the equatorial diameter (ED) of the fruits and peel thickness $(\mathrm{PT})$ were determined with an electronic digital vernier. Also, ${ }^{\circ}$ Brix were measured with a portable digital refractometer, all treatments were individually evaluated on 100 fruits.

The severity evaluation was carried out for 6 months on 100 trees. An arithmetic severity scale was used in which the following classes were considered: $1=$ Plant free of damage, $2=$ Plant with up to $25 \%$ damage on the total of foliar area, $3=$ Plant with damage greater than $25 \%$ up to $50 \%$ damage, $4=$ Plant with damage greater than $50 \%$ up to $75 \%$ damage and $5=$ Plant with damage greater than $75 \%$ damage. To determine the affected foliar area (severity), the severity scale proposed by Flores-Sánchez et al. (2015) was followed.

The severity percentage was calculated with the formula:

$$
\text { I.D. }=(n 1(1)+n 2(2)+n 3(3)+n 4(4)+n 5(5) / N T * 5) * 100
$$

Where I.D. is the intensity of damage, $n 0(0) \ldots n(5)=$ Total number of plants per degree of damage, $N T$ is the total number of plants evaluated and 5 is the maximum degree of damage on the scale.

During the period from September 2019 to March 2020, the chlorophyll content was monthly sampled with a Minolta SPAD meter during the day, three leaves were sampled in each of the 100 assessed trees. Four readings were taken per leave and automatically averaged by the equipment: one in the center and the remaining three in the contour. The above cover a larger leaf area and have a more accurate reading. For the experimental design, five treatments were carried out under a randomized blocks design and four repetitions (20 plants per treatment). The data obtained were analyzed using the $\mathrm{SAS}^{\circledR} \mathrm{V} 9$ statistical software and a comparison of means was made with the Tukey test $(\mathrm{P}=0.05)$.

\section{RESULTS AND DISGUSSIONS}

The ${ }^{\circ}$ BRIX between the different treatments showed significant differences. The highest sugar contents were presented in ULP-80, Vacciplant Max and the control. However, Bio-Fom and Fosetyl Aluminum showed 9\% less ${ }^{\circ}$ BRIX compared to UPL-80, which was the best treatment (Table 2). Flores-Sánchez et al. (2015) did not report differences in ${ }^{\circ}$ BRIX between fruits of asymptomatic and symptomatic branches in Persian lemon. On other hand, Soto et al. (2018) reported that when using microorganisms such as the SG-6 Paenibacillus polymyxa bacterium strain in the post-harvest decay of mandarins, caused by $P$. digitatum, and P. italicum did not affect SST.

At the same time, significant differences were observed in the equatorial diameter of the fruits. Their diameter in the Fosetil Aluminum treatment $(70.19 \mathrm{~mm})$ was $6.2 \%$ higher in contrast to the Bio-Fom $(65.84 \mathrm{~mm})$ treatment. However, the thickening of the 
peel presented the lowest thickness in the control treatment. Similarly, Vacciplant Max applications showed a $12.4 \%$ reduction of the mesocarp and exocarp (Table 2). Several authors point out that fruits of Citrus sinensis (L.) Osbeck cv. Valencia, harvested from trees positive for Candidatus Liberibacter asiaticus, shows a greater thickening of the peel compared to fruits harvested from healthy trees (Pérez et al., 2009; Flores Sánchez et al., 2015). Therefore, because in the control treatment there was a decrease in peel thickness, it concurs with Robles-González et al. (2013), who noted that the disease does not affect peel thickness. Regarding the weight of the fruits, the Fosetil Aluminum treatment (208.28 g) showed 15.7\% greater heaviness. However, when Bio-Fom was applied, lower weight fruits were observed (175.77 g) (Table 2). Pabón-Villalobos and Castaño-Zapata (2015) indicate that by applying fosetyl aluminum + propamocarb injected to the stem, an increase in the fruits' weight was achieved with a production of $421.40 \mathrm{~kg} \mathrm{ha}^{-1}$. However, Ruiz-Sánchez et al. (2008) observed in the melon (Cucumis melo) crops no differences in the weight of the fruits with Fosetil Aluminum.

Weight $(\mathrm{P})$ was determined with an analytical balance, the equatorial diameter $(\mathrm{ED})$ of the fruits and peel thickness $(\mathrm{PT})$

\section{Chlorophyll assessment in plants with Huanglongbing}

The highest chlorophyll index was obtained from the BIO-FOM (64.24) treatment, followed by the control and UPL-08 with 63.84 and 63.00, respectively (Table 3). By applying these agrochemicals, the chlorophyll content was increased by up to $2.4 \%$. On the contrary, the treatment that least contributed to this study variable was Fosetyl

Table 2. Comparison of means of the different treatments.

\begin{tabular}{l|c|c|c|c}
\multicolumn{1}{c|}{ Treatments } & ${ }^{\circ}$ Brix & ED $(\mathbf{m m})$ & $\mathbf{S T}(\mathbf{m m})$ & $\mathbf{w}(\mathbf{g})$ \\
\hline Vacciplant Max & $13.31 \mathrm{a}$ & $68.80 \mathrm{a}$ & $4.05 \mathrm{~b}$ & $187.53 \mathrm{bc}$ \\
\hline Control & $13.13 \mathrm{a}$ & $68.01 \mathrm{ab}$ & $3.87 \mathrm{~b}$ & $201.91 \mathrm{ab}$ \\
\hline BIO-FOM & $12.39 \mathrm{~b}$ & $65.84 \mathrm{~b}$ & $4.50 \mathrm{a}$ & $175.77 \mathrm{c}$ \\
\hline UPL-08 & $13.42 \mathrm{a}$ & $68.36 \mathrm{ab}$ & $4.47 \mathrm{a}$ & $187.53 \mathrm{bc}$ \\
\hline Fosetyl aluminum & $12.22 \mathrm{~b}$ & $70.19 \mathrm{a}$ & $4.62 \mathrm{a}$ & $208.28 \mathrm{a}$ \\
\hline DMS & 0.67 & 2.71 & 0.31 & 18.54 \\
\hline
\end{tabular}

ED: equatorial diameter, ST: shell thickness, w: weight, *Values with the same letter are statistically equal based on the Tukey test $(\mathrm{P} \leq 0.05)$. DMS: Minimum significant difference.

Table 3. Chlorophyll content and severity of Huanglongbing comparison.

\begin{tabular}{l|c|c}
\hline Treatments & Chlorophyll content & Severity (\%) \\
\hline Vacciplant Max & $62.68 \mathrm{~b}$ & $51.25 \mathrm{a}$ \\
\hline Control & $63.84 \mathrm{ab}$ & $51.25 \mathrm{a}$ \\
\hline BIO-FOM & $64.24 \mathrm{a}$ & $51.25 \mathrm{a}$ \\
\hline UPL-08 & $63.00 \mathrm{ab}$ & $55.0 \mathrm{a}$ \\
\hline Fosetyl aluminum & $62.71 \mathrm{~b}$ & $48.75 \mathrm{a}$ \\
\hline DMS & 1.50 & $17.61 \mathrm{a}$ \\
\hline
\end{tabular}

*Values with the same letter within columns are statistically equal based on the Tukey test $(\mathrm{p} \leq 0.05)$. DMS: Minimum Significant Difference. 
Aluminum (62.71). Likewise, as time passed, the chlorophyll index varied in each treatment (Figure 1). In September, values that ranged between 63 and 66 SPAD units were obtained. Subsequently, there was an increase by October and the index decreased in the two subsequent months, to rise again in February. It is important to note that the plant begins to expend more energy because their fruit also begins to mature, temperatures start to rise and have therefore an effect on the amount of chlorophyll. Finally, the lowest readings were recorded during March. However, BIO-FOM had the highest chlorophyll values in all treatments; therefore, it is attributed that the biofertilizer did not affect the plants, since such effect takes longer. Reyes-Santamaría et al. (2000) mention that, from October to February, the plants accumulate a greater amount of reserve carbohydrates to be used during the floral differentiation, in the initial vegetative growth and fruiting. However, from March to July the carbohydrates concentration decreases due to the vegetative growth, flowering, set and fruit development. Latsague $e t$ al. (2014) observed that the chlorophyll contents were influenced by NPK application in leaves of B. corallina. Likewise, the chlorophyll content increase has been observed with nitrogen fertilization by Warren et al. (2005) in leaves of Pinus pinaster Aiton Seneweera et al. (2011).

\section{Determination of the severity of Huanglongbing}

The severity did not show significant differences. However, fosetil aluminum reduced the severity of Huanglongbing by $11.4 \%$ in orange cv. Valencia compared to the rest of the treatments. Likewise, the trees treated with UPL-80 showed the highest disease severity percentage (12.8\%). In general, in the period from September to November, the severity percentage remains below $15 \%$ in all treatments (Figure 2). On other hand, as of January, the severity exponentially rises, until reaching the highest percentage of damage in March. Previous research states that the Candidatus Liberibacter asiaticus bacteria concentration increases as its presence in the plant pass. In addition, factors such as temperature, relative humidity and precipitation affect pathogen proliferation. This last factor causes buds in citrus fruits in September; therefore, there is a greater food source and shelter for the Huanglongbibg vector, the Asian psyllid Diaphorina citri.

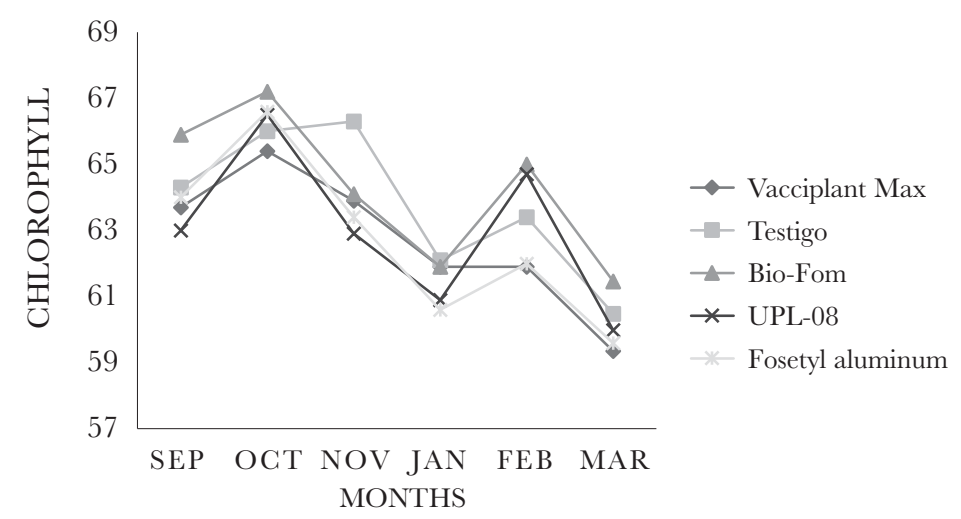

Figure 1. Chlorophyll content percentages from September 2019 to March 2020 in Citrus sinensis Osbeck cv. Valencia. 


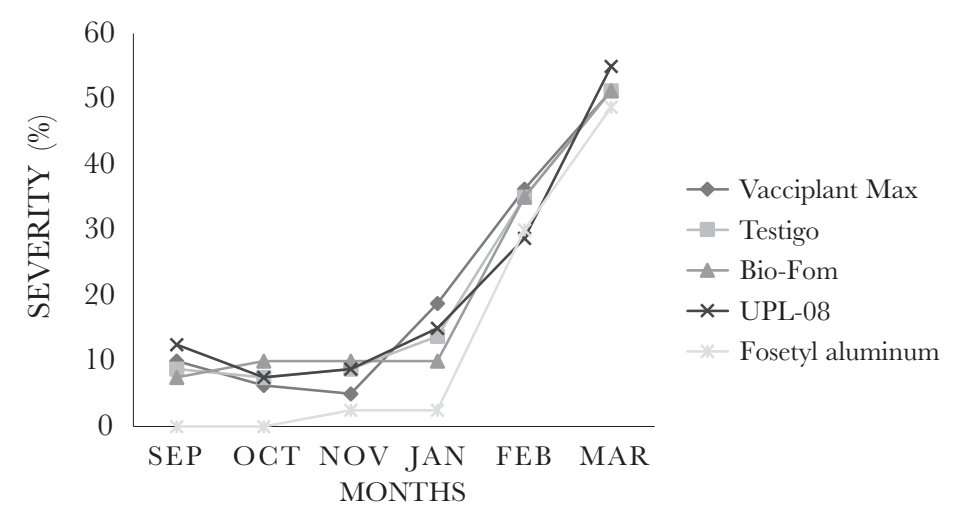

Figure 2. Severity percentages from September 2019 to March 2020 in Citrus sinensis Osbeck cv. Valencia.

In sweet orange, the symptoms are less intense, since the generalized yellowing of the leaf blade occurs infrequently and defoliation of these is not observed as mentioned by Flores-Sánchez et al. (2015). Also, Quiroga and Arbeláez (2004) mentioned that with Fosetil Aluminum the lowest severity values of the downy mildew disease were recorded in roses cultivation. At the same time, Ruiz-Sánchez et al. (2008) noted that the severity of the downy mildew disease (Pseudoperonospora cubensis Berk. \& Curt.) Rost. in melon (Cucumis melo L.) cultivation decreased due to Fosetyl Aluminum.

\section{GONGLUSIONS}

The best treatment against Huanglongbing was Fosetyl aluminum as it gave greater weight $(15.7 \%)$ and fruit diameter (6.2\%). Similarly, fruits from trees treated with Vacciplant Max presented lower peel thickness and higher ${ }^{\circ} \mathrm{BRIX}$ content. In addition, the highest chlorophyll index was achieved with the Bio-Fom fertilizer. However, none of the evaluated treatments significantly decreased the severity percentage in the orange cv. Valencia.

\section{ACKNOWLEDGEMENTS}

To the producer Ing. Ernesto Castañeda Bernal for the facilities granted to carry out this research, to the Universidad Autónoma de Tamaulipas, the Faculty of Engineering and Sciences and the Consejo Nacional de Ciencia y Tecnología (CONAGyT).

\section{REFERENGES}

Acuña G., E.M., \& Grabowski O, G. (2012). Inducción de resistencia en plantas de trigo (Triticum aestivum L.) a la mancha amarilla (Drechslera tritici-repentis) y marrón (Bipolaris sorokiniana). Investigación Agraria 14: 71-79.

Alayón L., P., Rodríguez, V.A., Píccoli, A.B., Chabbal, M.D., Giménez, L.I., \& Martínez, G.C. (2014). Fertilización foliar con macronutrientes a plantas de naranja Valencia late (Citrus sinensis (L.) Osbeck) y tangor Murcott (Citrus reticulata Blanco $\times$ Citrus sinensis (L.) Osbeck). Revista de la Facultad de Ciencias Agrarias 46:87-96.

Gurtolo, M., Granato, L.M. \& Soratto T., A.T., Curtolo, M., Gazaffi, R., Takita, M.A., Cristofani-Yaly, M., \& Machado, M.A. (2020). Expression Quantitative Trait Loci (eQTL) mapping for callose synthases in intergeneric hybrids of Citrus challenged with the bacteria Candidatus Liberibacter asiaticus. Genetics and Molecular Biology 43:1-16. doi: 10.1590/1678-4685-gmb-2019-0133

Flores-Sánchez, J.L., Mora-Aguilera, G., Loeza-Kuk, E., López-Arroyo, J.I., Domínguez-Monge, S., AcevedoSánchez, G., \& Robles-García, P. (2015). Pérdidas en Producción inducidas por Candidatus Liberibacter asiaticus en Limón Persa, en Yucatán México. Revista Mexicana de Fitopatología 33:195-210. 
Garza-Saldaña, J.J., Varela-Fuentes, S., \& Gómez-Flores, W. (2017). Métodos para la detección presuntiva de Huanglongbing (HLB) en cítricos. CienciaUAT 11: 93-104.

Hernández H., R., Granados R., G.R., Mora A., G., Aguirre G., R., \& León G., I. (2019). Reconversión de cultivos como resultado de la presencia de Huanglongbing en Colima, México. Acta Universitaria 29:1-13. doi: 10.15174/au.2019.1921

Latsague, M., Sáez D., P., \& Mora, M. (2014). Efecto de la fertilización con nitrógeno, fósforo y potasio, sobre el contenido foliar de carbohidratos, proteínas y pigmentos fotosintéticos en plantas de Berberidopsis corallina Hook.f. Gayana Botanica 71:37-42.

Pabón-Villalobos, J., \& Castaño-Zapata, J. (2015). Evaluación de productos químicos y uno biológico para el manejo de Phytophthora spp. en naranjo 'salustiana' injertado en portainjerto sunki. Revista U.D.C.A Actualidad y Divulgación Científica 18: 339- 349.

Quiroga B., N.J., \& Arbeláez T., G. (2004). Evaluación de la eficacia de fungicidas aplicados al suelo y al follaje para el control de mildeo velloso, ocasionado por Peronospora sparsa en un cultivo comercial de rosa. Agronomía Colombiana 22: 110-118.

Ramírez G., M., \& Rodríguez, A. (2012). Mecanismos de defensa y respuestas de las plantas en la interacción micorrícica. Revista Colombiana de Biotecnología 14: 271-284.

Reyes-Santamaría, M.I., Villegas-Monter, A., Colinas-León, M.T., \& Calderón-Zavala, G. (2000). Peso específico, contenido de proteína y de clorofila. Agrociencia 34: 49-55.

Robles-González, M.M., Orozco-Santos, M., Manzanilla-Ramírez, M.A., Velázquez-Monreal,J.J., \& CarrilloMedrano, S.H. (2017). Efecto del HLB sobre el rendimiento de limón mexicano en Colima, México. Revista Mexicana de Ciencias Agrícolas 8: 1101-1111.

Robles-González, M.M., Velázquez-Monreal, J.J., Manzanilla-Ramirez, M.A., Orozco-Santos, M., MedinaUrrutia, V.M., López-Arroyo, J.I., \& Flores-Virgen, R. (2013). Síntomas del Huanglongbing (HLB) en árboles de limón mexicano [Citrus aurantifolia (Christm) Swingle] y su dispersión en el estado de Colima, México. Revista Chapingo. Serie Horticultura 19: 15-31.

Ruiz-Sanchez, E., Tún-Suárez, J.M., Pinzón-López, L.L., Valerio-Hernández, G., \& Zavala-León, M.J. (2008). Evaluación de fungicidas sistémicos para el control del mildiú velloso (Pseudoperonospora cubensis Berk. \& Curt.) Rost. en el cultivo del melón (Cucumis melo L.). Revista Chapingo. Serie Horticultura 14:79-84.

Sáenz P., C. A., Osorio H., E., Estrada D., B., Poot P., W.A., Delgado M., R., y Rodríguez H., R. (2019). Principales enfermedades en cítricos. Revista Mexicana de Ciencias Agrícolas 10:1653-1665.

Seneweera, S., Makino, A., Hirotsu, N., Norton, R., \& Suzuki, Y. (2011). New insight into photosynthetic acclimation to elevated CO2: The role of leaf nitrogen and ribulose-1,5- bisphosphate carboxylase/ oxygenase content in rice leaves. Environmental and Experimental Botany 71: 128-136.

Sharif, M., Attique K., M., Iqbal Z., Faisal A., M., I. Ullah L., M.I., \& Younus J., M. (2018). Detection and classification of citrus diseases in agriculture based on optimized weighted segmentation and feature selection. Computers and Electronics in Agriculture 150:220-234.

Soto C., F., Tramón P., G., Aqueveque M., P., \& De Bruijn, J. (2018). Microorganismos antagonistas que inhiben el desarrollo de patógenos en post-cosecha de limones (Citrus limon L.). Chilean Journal of Agricultural \& Animal Sciences 32: 173-184.

Spreen, T. H., Gao Z., Fernandes W., \& Zansler, M. L. (2020). Global economics and marketing of citrus productsIn: Talón, M., Caruso M., \& Gmitter, F. G. (Eds.). The Genus Citrus. Elsevier. España. pp:471-493.

Trinidad-Cruz, J.R., Rincón-Enríquez, G., Quiñones-Aguilar, E.E., Arce-Leal, A.P., \& Leyva-López, N.E. (2019). Inductores de resistencia vegetal en el control de Candidatus Liberibacter asiaticus en árboles de limón (Citrus aurantifolia) mexicano. Revista Mexicana de Fitopatología 37:1-14.

Warren, Ch.R., Mcgrath, J.F., \& Adams, M.A. (2005). Differential effects of N, P and K on photosynthesis and partitioning of $\mathrm{N}$ in Pinus pinaster needles. Annals of Forest Science 62: 1-8. 